\title{
Interrupting a joke validates thoughts and polarizes attitudes towards a recycling company / La interrupción de un chiste puede potenciar su efecto de validación del pensamiento y cambiar las actitudes hacia una empresa de reciclaje
}

David Santos, Maria Stavraki, Beatriz Gandarillas, Ana Cancela \& Pablo Briñol

To cite this article: David Santos, Maria Stavraki, Beatriz Gandarillas, Ana Cancela \& Pablo Briñol (2018) Interrupting a joke validates thoughts and polarizes attitudes towards a recycling company / La interrupción de un chiste puede potenciar su efecto de validación del pensamiento y cambiar las actitudes hacia una empresa de reciclaje, Revista de Psicología Social, 33:3, 529-554, DOI: 10.1080/02134748.2018.1483623

To link to this article: https://doi.org/10.1080/02134748.2018.1483623

2018.

Џ Article views: 80
Submit your article to this journal $\square$

View Crossmark data $[\pi$ 


\title{
Interrupting a joke validates thoughts and polarizes attitudes towards a recycling company / La interrupción de un chiste puede potenciar su efecto de validación del pensamiento y cambiar las actitudes hacia una empresa de reciclaje
}

\author{
David Santos $\oplus^{\mathrm{a}}$, Maria Stavraki ${ }^{\mathrm{b}}$, Beatriz Gandarillas ${ }^{\mathrm{c}}$, Ana Cancela ${ }^{\mathrm{d}}$, \\ and Pablo Briñol ${ }^{\mathrm{a}}$ \\ ${ }^{a}$ Universidad Autónoma de Madrid; ${ }^{b}$ Universidad de Castilla La Mancha; ${ }^{c}$ Universidad \\ Francisco de Vitoria; ${ }^{d}$ Centro Universitario Villanueva
}

(Received 11 April 2017; accepted 30 May 2018)

\begin{abstract}
Positive emotions can validate either positive or negative thoughts. Previous research has demonstrated that people use their thoughts more when they recall past episodes of happiness and when they are induced to smile. This study was designed to evaluate whether a new induction of a happy mood (a joke) can influence thought use in response to a persuasive proposal. Two versions of the same joke were compared: a version that included an interruption before the punchline and another that did not include an interruption at that point. The aim was to examine whether this interruption increased or decreased the use of previously generated thoughts towards a persuasive communication. The results indicated that the participants who were interrupted before the punchline relied more on their own thoughts in forming their attitudes than did those who were in the control group. In consequence, an interruption during a pleasant experience (e.g., a joke) increased persuasion when thoughts were positive but decreased persuasion when thoughts were negative.
\end{abstract}

Keywords: joke; humour; interruption; attitudes; validation

Resumen: Las emociones positivas pueden validar tanto pensamientos positivos como pensamientos negativos. La investigación previa ha demostrado que las personas utilizan más sus pensamientos después de recordar episodios felices y cuando se inducen expresiones faciales asociadas con sonrisa. Esta investigación evaluó en qué medida una nueva inducción de estado de ánimo positivo (un chiste) influye en el uso de los pensamientos generados previamente en respuesta a una propuesta persuasiva no relacionada con el chiste. Para ello, se compararon dos versiones de un mismo chiste: una versión que incluía una interrupción antes del desenlace y otra en la que no se incluía

English version: pp. 529-540 / Versión en español: pp. 541-552

References / Referencias: pp. 552-554

Translated from Spanish/Traducción del español: Mary Black

Authors' Address / Correspondencia con los autores: Pablo Briñol, Departamento de Psicología, Universidad Autónoma de Madrid, Campus de Cantoblanco, Crta. Colmenar, Km. 15, 28049 Madrid, España. E-mail: pablo.brinnol@uam.es 
dicha interrupción en ese momento. Los resultados mostraron que aquellos participantes interrumpidos antes del desenlace del chiste usaron más sus pensamientos al formar actitudes que aquellos en el grupo control. Como consecuencia, una interrupción durante una experiencia placentera (e.g., un chiste) aumentó la persuasión cuando los pensamientos fueron positivos pero disminuyó la persuasión cuando los pensamientos fueron negativos.

Palabras clave: chiste; humor; interrupción; actitudes; validación

The most recent research on emotion and cognition suggests that emotions can validate thoughts (Boden, Berenbaum, \& Gross, 2016; Clore \& Huntsinger, 2009; Huntsinger, Isbell, \& Clore, 2014). Applied to the context of changing attitudes, a positive emotion like happiness can increase or decrease persuasion depending on the direction of the thoughts. If a person's thoughts are favourable towards a persuasive proposal, then happiness (unlike sadness) will facilitate the use of these positive thoughts, leading to more persuasion. On the other hand, if the person's thoughts are unfavourable, happiness (unlike sadness) will facilitate the use of these negative thoughts, giving rise to less persuasion. This thought-enhancing effect is due to a sense of self-assurance (believing that one is right and correct) and a sense of wellbeing (feeling good with what comes to mind). If a person feels good and trusts the validity of positive thoughts, then persuasion increases; however, if a person feels good and trusts the validity of negative thoughts, persuasion decreases.

This metacognitive approach is consistent with appraisal theories of emotion, according to which cognitive interpretations of a situation influence emotions, and emotions influence cognitive interpretations of a situation (Keltner \& Lerner, 2010; Smith \& Ellsworth, 1985). For example, emotions contain valence dimensions which help us draw closer to what we like and distance ourselves from what we do not like. In our metacognitive application of this approach (Petty \& Briñol, 2015), emotions inform people of the thoughts that attract them and make them feel good and of the thoughts that they reject and do not make them feel good. Emotions also contain information on other aspects beyond valence. For example, some emotions such as happiness not only make us feel good but are also associated with a sense of security and confidence (Moors, Ellsworth, Scherer, \& Frijda, 2013). Applied to the interpretation of our own thoughts, happiness makes us feel good and confident about what we have in mind, while other emotions like sadness make us feel worse and less confident about what we think.

In a first illustration of this possibility, Briñol, Petty, and Barden (2007) carried out a series of experiments in which the participants first received a persuasive message comprised of strong arguments or a message comprised of weak arguments. This manipulation sought to affect the direction of the thoughts generated, producing more favourable thoughts towards the message after having read the strong arguments than after reading the weak ones. Then, participants' mood was manipulated by asking them to write about personal experiences in which they felt happy or sad. After this initial manipulation, all participants reported on their attitudes towards the message's proposal. As expected, it was found that 
happiness increased people's trust in their thoughts, and this confidence led to more favourable attitudes towards the persuasive proposal when the thoughts were positive and less favourable attitudes when the thoughts were negative.

For the first time in the sphere of attitude change, this study demonstrated that positive emotions can operate through processes of thought validation in response to persuasive messages. Later, Paredes, Stavraki, Briñol, and Petty (2013) replicated these effects by inducing happiness through the facial expressions of smiling and examining their effect on the use of thoughts. In this study, the participants were first exposed to a story designed to provoke primarily positive thoughts (description of an employee's good day at work) or negative thoughts (description of an employee's bad day at work). After writing their thoughts, the participants were asked to hold a pen in their teeth to force a smile-like expression (smile conditions) or with their lips (control condition). Finally, all the participants reported to what extent they liked the story they had read. According to the self-validation hypothesis, it was found that the effect of the initial direction of the thoughts on the evaluation of the story was greater for the smiling participants than for the participants in the control group. Smiling increased the positive impact of positive thoughts and also increased the negative impact of negative thoughts. These results conceptually replicated the results of previous studies on corporal cognition (embodiment), but only when the participants had positive thoughts. That is, inducing an expression associated with a smile led to more favourable evaluations (Strack, Martin, \& Stepper, 1988) when positive thoughts had been generated but showed the pattern counter to these results (less favourable evaluations for the smile condition) for negative thoughts (see Briñol, Petty, Santos, \& Mello, 2017 for a review).

This research examines the effect of thought validation based on another variable that is often associated with positive moods. Instead of asking the participants to remember past happy events or subtly inducing them to adopt facial expressions associated with smiling, in this study we exposed participants to a joke. Because jokes can make people laugh and feel good, one might expect that a joke would lead to more use of thoughts, as in the case of the inductions previously studied in this paradigm. This study compares two versions of the same joke: one version which is interrupted before the punchline and another version in which this interruption did not take place before the punchline. The main reason why an interruption was introduced was to examine to what extent it may enhance or undermine the effect of the joke in relation to the use of thoughts. Evaluating whether the effect of thoughts increases or decreases when forming an attitude allows us to study to what extent interruption is a variable that validates or invalidates thoughts. In theory, we can point to a series of reasons a priori that suggest that the effect of interrupting a joke may heighten its effect on humour, thereby increasing the use of thoughts within the context of persuasion.

First, an interruption may enhance the effect of a joke because it slows down the adaptation to positive experiences (Schmitt \& Zarantonello, 2013). This explanation is consistent with the results of different studies showing that participants who were interrupted in the middle of a positive experience (e.g., getting a 
massage, watching their favourite TV programme) evaluated their experience as more pleasant than those who received the same pleasant experience continuously (Nelson \& Meyvis, 2008; Nelson, Meyvis, \& Galak, 2009).

Secondly, the interruption may provide a space for people to think about the experience that is about to happen and in consequence anticipate how good it is going to be. That is, people generate expectations of what awaits them after the pause, and since the experience was already pleasant they are more likely to expect that it will continue to be pleasant afterward. This interpretation is also consistent with what is called the phenomenon of mere thought, according to which the more one thinks about something the more the initial evaluative response is polarized (Clarkson, Tormala, \& Leone, 2011; Tesser \& Conlee, 1975). In line with this idea, Kupor and Tormala (2015) demonstrate that an interruption in a persuasive message can increase consumers' processing of the message.

Thirdly, in addition to slowing down the adaptation to pleasure and increasing the expectations generated, there are other reasons why interruptions may increase the effect of a joke. For example, according to Dijksterhuis, Bos, Nordgren, and Van Baaren (2006), when decisions are interrupted, people process the information on a product according to their wishes, and therefore they choose the options that are desirable instead of those that are feasible.

Fourthly, Zeigarnik $(1927,1938)$ argues that interrupting a task before it is finished causes a feeling of unresolved tension and a pressing need to complete it. This tension, in turn, means that they earmark cognitive resources to the interrupted task, thus leading to a better recollection of interrupted tasks than uninterrupted tasks. This view is consistent with the study by Speier, Vessey, and Valacich (2003) which found that due to the increased arousal caused by the tension produced by interrupted tasks, subsequent performance on different tasks improved, especially simpler tasks (Bailey \& Konstan, 2006; Speier, Valacich, \& Vessey, 1999). Applied to the field of attitudes, Pérez, Falomir, and Mugny (1995) found that interrupting a task related to presenting arguments in a minority influence paradigm increased the persuasive effects of those arguments.

\section{Hypothesis and objective}

In summary, interrupting a joke may enhance its effect because it increases the intensity of the pleasant experience and lowers the adaptation with which people usually adjust to moods that are pleasant. If we take these interpretations as a whole, it could be expected that interrupting a joke has the potential to increase the use of any thought which a person may have in mind. In order to test this possibility, in this study we used a paradigm in which we evaluated the effect of interrupting a joke in relation to the use of the thoughts available at that time when forming attitudes.

It is worth noting that depending on the extent to which a person experiences the interruption as a loss of control and power (Briñol, Petty, \& Stavraki, 2012), an opportunity to rationalize the emotional experience (Wilson \& Gilbert, 2003) 
or a space for thoughts in a valence opposite to the initial one that came to mind (Tormala, Falces, Briñol, \& Petty, 2007), the effect of the interruption could decrease (instead of increase) the use of thoughts. Finally, it is possible that interrupting the joke has no effect in relation to the use of thoughts about persuasive proposals in a paradigm of self-validation. The following study was conducted with the goal of clarifying these different possibilities.

\section{Method}

\section{Participants and design}

Seventy-one students from the Autonomous University of Madrid participated anonymously and voluntarily in this study (eight males, 61 females and two without data, with an age range of 21 to $27 ; M_{\text {age }}=21.76 ; S D=1.18$ ). The participants were randomly assigned the conditions of a 2 (quality of the arguments: strong vs. weak) x 2 (joke: interruption before the punchline vs. control) intersubject factorial design.

\section{Procedure}

The research was presented as a study on the organizational characteristics of the work environment of different companies. The participants were given questionnaires which contained the tasks that they had to perform and the instructions they needed to do so. Before the session started, all the participants were briefed on the confidentiality and anonymity of the research, and their informed consent was obtained. First, the participants were instructed to carefully read a complete description of a newly-created recycling company. Specifically, the description of the company was favourable in all aspects and was made up of either strong or weak arguments in favour of the idea that it was an effective recycling company. After reading this information, the participants listed their thoughts about the company. Once they had written their thoughts, all the participants were given a joke in the guise of a comic strip. Specifically, the participants in the condition of interruption before the punchline were asked to stop reading the comic strip before the joke's punchline was presented, while the participants in the control condition were asked to stop reading after the joke's punchline. Finally, all the participants evaluated the company, filled out a few additional measures, were thanked for their participation, were debriefed - while also being offered the possibility of obtaining more information about it - and were asked for their consent in order to proceed to the data analysis.

\section{Independent variables}

Argument quality. The participants received a message about the new recycling company. This message was comprised of strong arguments about the company in one condition or weak arguments in the other condition. This manipulation was designed to influence the favourability of the participants' cognitive responses to 
the company, and its efficacy has been proven in previous studies (Horcajo, Petty, \& Briñol, 2010). That is, the strong arguments mostly generated favourable thoughts about the company while the weak arguments mostly generated unfavourable thoughts (for example, on manipulating the quality of the arguments in Spanish, see Gandarillas, Requero, Rojo, \& Briñol, 2014). Some of the strong arguments in favour of the company were that the workers reported higher satisfaction due to flexible working hours and the company's investment in training, that they had total freedom and autonomy to innovate, that promotion decisions were taken based on the workers' merits instead of favouritism, that the company invested in renewable energies and used environmental protection policies, and that it was guided by equality policies (e.g., with a larger number of women in managerial posts). On the contrary, some of the weak arguments in favour of the company were that it used non-recycled paper to ensure a good public image, that the company's logo was very attractive, that the offices projected an environmentally respectful image since there were many plants around them, that it was concerned with its employees by having vending machines in the offices and that the company was concerned with flexibility since many employees only worked there temporarily. The arguments were designed and pre-tested to induce primarily positive thoughts (in response to the strong arguments of the message) or negative thoughts (in response to the weak arguments of the message).

Joke. After reading the message and listing their thoughts, the participants were exposed to a comic strip with six frames. The same joke was used in both conditions. In the condition of interruption before the punchline, the participants were shown the six frames on one page, but the last two were blank, thus only allowing them to see four frames of the joke. The participants were asked to stop for two minutes before reading the last two frames, which were on the next page. That is, the participants stopped right before the joke's punchline was presented. However, in the control condition, the participants were shown all six frames on one page and were asked to stop after reading the entire comic strip and then to wait two minutes before continuing with the rest of the study. That is, the participants in this condition saw the entire comic strip, including the joke's punchline. After seeing the entire comic strip, the participants received instructions to stop for two minutes before continuing with the rest of the study so that both conditions were comparable in terms of the total presentation time.

\section{Dependent variables}

Thought favourability. The participants were instructed to list the thoughts they had while reading the message. They were given 10 boxes to list 10 thoughts. They were told that they had to write one thought per box and that they should not worry about the grammar (for additional details on the thought-listing task, see Briñol, Petty, \& Tormala, 2004; for another example in Spanish, see MartínFernández, Santos, Requero, \& Cedeño, 2014). At the end of the experiment, 
the participants were once again presented with the thoughts they had written and were asked to classify them as positive, negative or neutral with regard to the company. A thought favourability index was created for each participant by subtracting the number of negative thoughts from the number of positive thoughts that each had listed. Finally, this differential score was divided by the total number of thoughts listed.

Attitudes. The participants were asked to evaluate the company using a series of differential nine-point semantic scales (1-9) (i.e., 'not at all interesting-very interesting', 'not at all useful-very useful', 'not at all recommendable-very recommendable', 'not at all desirable as a workplace-very desirable as a workplace', 'dislike-like'). Due to the high internal correlation presented by these five items $(\alpha=.96)$, a general index of attitudes towards the company was composed for each participant with the mean of their scores. Higher values on this scale indicated greater favourability towards the company.

Ancillary measures. After measuring attitudes, all the participants indicated the following on a scale of 1 to 9: the amount of attention they had paid to the study, the level of precision with which they had filled out the questionnaire, the degree to which they had tried to correct their responses, the degree to which they thought they had figured out the objective of the experiment, the degree to which the joke's punchline had surprised them, and the degree to which they had understood the joke.

\section{Results}

\section{Thought favourability}

A 2 (quality of the arguments: strong vs. weak) $\times 2$ (joke: interruption before the punchline vs. control) ANOVA performed on the participants' thoughts revealed a main effect of argument quality on thoughts, $F(1,66)=195.76, p<.001, \eta^{2}=.75$. As shown in Figure 1, the participants generated more favourable thoughts in the condition of strong arguments $(M=0.69, S D=0.34)$ than in the condition of weak arguments $(M=-0.71, S D=0.47)$. No other main effect or interaction was found, $p \mathrm{~s}>.094$.

\section{Attitudes}

A $2 \times 2$ ANOVA revealed a main effect of argument quality on attitudes, which indicated that the participants who received the strong message reported more favourable attitudes towards the company $(M=7.63, S D=0.95)$ than those who received the weak message $(M=3.32, S D=1.30), F(1,67)=258.84, p<.001$, $\eta^{2}=.79$. Furthermore, as expected, the interaction between the quality of the arguments and the joke was statistically significant, $F(1,67)=7.18, p=.009$, $\eta^{2}=.10$. For the participants who read the joke but stopped before the punchline, those who received the strong message evaluated the company more favourably 


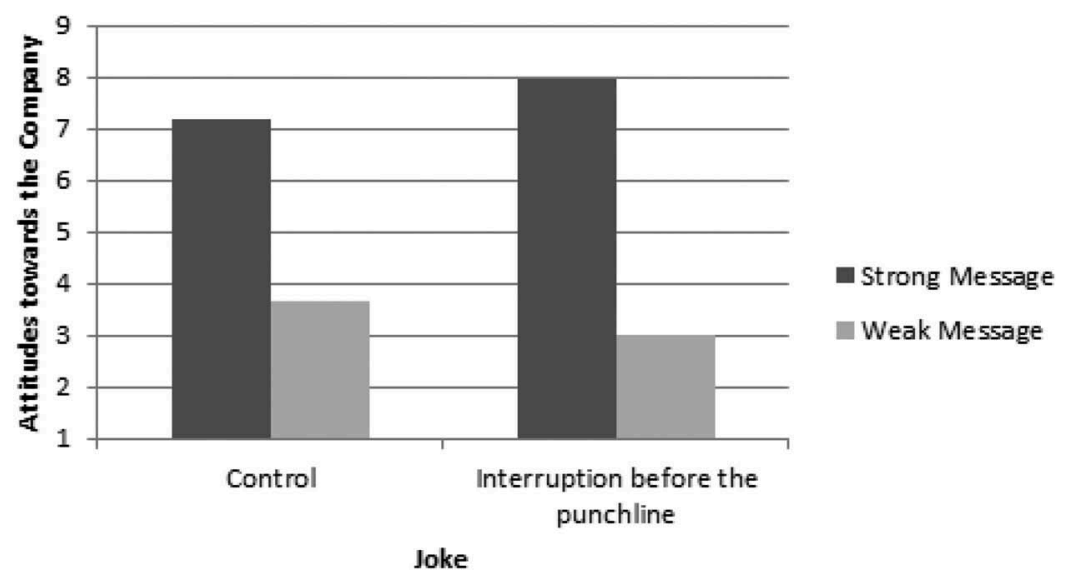

Figure 1. Attitudes towards the company according to argument quality and.

$(M=7.95, S D=0.99)$ than those who received the weak message $(M=3.01$, $S D=1.27), F(1,67)=195.71, p<.001, \eta^{2}=.75$. On the other hand, among the participants who read the entire joke and then stopped afterwards (control condition), those who received the strong message also reported more favourable attitudes towards the company $(M=7.20, S D=0.73)$ than those who received the weak message $(M=3.67, S D=1.28), F(1,67)=81.72, p<.001, \eta^{2}=.55$, although this difference was smaller than in the participants who stopped before the joke's punchline. That is, the effect of argument quality on attitudes was stronger for participants who stopped before reading the punchline than for the participants in the control condition.

Put differently, this interaction demonstrates that in the condition of the strong message, the participants who stopped before the punchline reported more favourable attitudes towards the company $(M=7.95, S D=0.99)$ than the participants in the control condition $(M=7.20, S D=0.73), F(1,67)=3.97, p=.050, \eta^{2}=.06$. On the contrary, among the participants in the weak message condition, those who stopped before the punchline tended to report less favourable attitudes $(M=3.01$, $S D=1.27)$ than those in the control condition $(M=3.67, S D=1.28), F(1$, $67)=3.22, p=.077, \eta^{2}=.05$.

\section{Thoughts-attitudes linkage}

One of the predictions of self-validation is that the connection between thoughts and attitudes should be higher for the validation condition than for the control group. To check this hypothesis on the relationship between thoughts and attitudes, a regression analysis was performed with argument quality, joke and thought favourability index as the predictive variables and attitudes as the dependent variable. As illustrated in Figure 2, the interaction between thought favourability and the joke was statistically significant, $B=-1.043, t(68)=-2.855, p=.006$. This interactive pattern indicated that even though the favourability of thoughts predicted attitudes in the entire sample, 


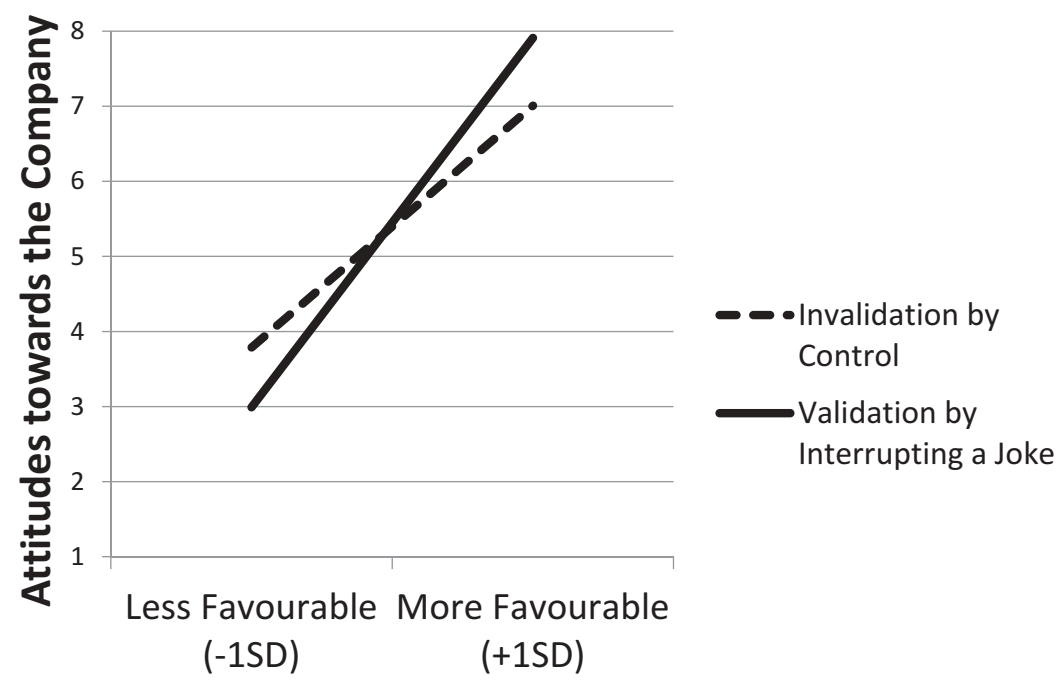

Thought Favourability

Figure 2. Relationship between thought favourability and attitudes as a function of validation by joke interruption (vs. control).

the relationship between these constructs was greater for the participants in the condition in which the joke was interrupted $(B=3.020, t(68)=13.117, p<.001)$ than for those in the control condition $(B=1.977, t(68)=6.971, p<.001)$.

\section{Ancillary measures}

No principal effect or interaction was found in any of the complementary items (i.e., precision, attention, degree of elaboration, correction, surprise and understanding), $p \mathrm{~s}>.16$.

\section{Discussion and conclusions}

The research into self-validation demonstrates that emotions like happiness validate people's thoughts. This validation of thoughts occurs regardless of whether these thoughts are positive or negative. As mentioned, this thought-enhancing effect is due to a sense of self-assurance (believing that one is right and correct) coupled with a sense of wellbeing (feeling good with what comes to mind). Unlike previous inductions of happiness studied to date (focused on the receiver), this study examined induction via a joke. Furthermore, it studied the effect of interrupting the joke in order to evaluate its possible effect on thought validation.

According to the results, the effect of thoughts on attitudes was stronger for the participants who had to stop before the joke's punchline than those who read the entire joke (control condition). In other words, the participants for whom the joke was interrupted used their thoughts more to shape their attitudes towards the company about which they had initially read than those who saw the entire joke. 
As described in the introduction, the interruption of a hedonistic experience may have positive effects because it heightens its intensity (Nelson \& Meyvis, 2008; Nelson et al., 2009). This positive effect could make people validate their thoughts and use them to make subsequent evaluations. That is, the positive effect of interrupting the joke could mean that they trust and like what they think more, forming attitudes coherent with the thoughts they had in mind at that moment. As a result of this thought validation, when the thoughts about the company were positive and the joke was interrupted, more favourable attitudes were formed about the company than when the joke was not interrupted. On the contrary, when people generated negative thoughts about the company and the joke was interrupted, they formed less favourable attitudes than when it was not interrupted.

Even though the results of the study suggest that an interruption can validate what people think, there are also other possible explanations which could explain the results. First, it could be argued that stopping before the joke's punchline affected the amount of thinking, thus increasing the elaboration of the initial message instead of influencing the use of those thoughts. In fact, the participants in the condition of the joke interrupted before the punchline had time to pay attention to the thoughts they had generated about the company. Even though this interpretation is plausible, we believe that it is not likely since the joked followed (as opposed to preceded) the reading of the message. That is, the participants were first exposed to the message, then they listed their thoughts, and then they saw the joke. This order of events makes it unlikely that the thoughts generated in response to the company were influenced by something that happened later. In fact, the participants listed the same number of thoughts under both conditions, which suggests that the condition of interruption before the punchline did not increase the amount of thinking compared to the condition of interrupting the joke after its punchline. Furthermore, when the participants were explicitly asked about how much attention they had paid to reading the messages, no difference was found according to the condition of the joke. Consequently, neither the objective indicators (number of thoughts listed) of the amount of thought nor the subjective indicators (attention) are consistent with this alternative interpretation.

Another possible explanation could be that interrupting the joke before the punchline affected the ease with which the joke was read or the readers' understanding of it, given that the interruption provided the participants not only with time to think about the company retrospectively but also time to think about the forthcoming punchline of the joke. In this way, the participants may have been able to generate hypotheses on how the joke would end. If one of these expectations were confirmed when the real punchline was presented, this could produce a match between the expectation and the result, and this convergence would increase the perceived ease of the task (Schwarz et al., 1991; Topolinski, 2014; for a survey, see Briñol, Tormala, \& Petty, 2013). Despite the potential value of this interpretation, which is not entirely incompatible with our proposal (since matching phenomena can increase the validity of thoughts; Clark, Wegener, Briñol, \& Petty, 2009; Clark, Wegener, Sawicki, Petty, \& Briñol, 2013), no differences were found between the interruption conditions in relation to the difficulty of understanding the joke. 
A third possibility would be that the participants had a greater need for cognitive closure when they stopped before the joke's punchline than when they stopped after it (Kruglanski, 2004). According to this explanation, the interruption may have motivated a need to resolve the situation with any information available at that time, which in this case was the thoughts generated previously about the company. Partly related to this possibility, the interruption may have meant a rupture in schemas and a violation of expectations which may have been unpleasant for the participants. It is known that confusion can be threatening in some cases, giving rise to a use of the thoughts available at that time as a way of offsetting the unease and restoring the lost order (Briñol, Petty, \& DeMarree, 2015).

Another alternative explanation is that the interruption may have increased the intensity of the joke, and this may in turn have led to a more global evaluation of thoughts or may have instead more precisely concentrated the participants' attention on relevant thoughts (without distractions) or even on a greater generalization spreading to other thoughts (Fredrickson \& Branigan, 2005; Horcajo, Briñol, \& Petty, 2010).

Future studies should have a larger number of measures that can shed light on some of these possibilities, such as the Need for Cognitive Closure Scale (for the Spanish-language version of this scale, see Horcajo, Díaz, Gandarillas, \& Briñol, 2011), as well as the direction and intensity of the emotions prompted in response to the joke. In future studies, it would also be worthwhile for the results to be replicated with different attitude objects and other ways of manipulating the interruption both within the context of humour and in other pleasant experiences (Briñol, Stavraki, Horcajo, \& Gandarillas, 2016). Finally, it is worth noting that one limitation of this study is that the current design does not enable us to definitively determine to what extent interrupting the joke increased the use of thoughts or to what extent the control group condition lowered the use of thoughts, or indeed whether there was a combination of both effects. Including a group without a joke would shed more light on this issue. In any event, the main objective of this study was to examine under what conditions a joke could lead to more or less use of thoughts.

To conclude, we should note that an interruption does not necessarily increase the effect of a joke in all situations and for all people. There are variables that can influence to what extent, when and why an interruption can heighten or lower the effect of an experience. For example, the interruption may lower the effect of a pleasant experience (the effect of a joke) in that it allows thoughts in the valence opposite to the one that initially came to mind (Forgas \& Ciarrochi, 2002; Koole \& Jostmann, 2004; Tormala et al., 2007), or it provides the opportunity to rationalize the emotional experience (Wilson \& Gilbert, 2003) when it is associated with a loss of control (Briñol, Petty, Valle, Rucker, \& Becerra, 2007; Briñol, Petty, \& Stavraki, 2012) and when it is perceived as a task that a person has been unable to resolve (Stavraki, Santos, Cancela, Requero, \& Briñol, 2017). In reality, any negative association with the interruption could lower (as opposed to increase) the effect on thoughts. Furthermore, if an interruption is unexpected, violates initial expectations or comes as a surprise, it could also reduce the use of 
thoughts, at least to the extent that people focus on these potential aspects of doubt and uncertainty.

With regard to the possible practical applications, consider the scenario in which a salesperson is trying to convince someone to purchase their company's products or services. After showing the value of their proposition, the salesperson uses a joke to close the sale. According to the results of this study, we could speculate that this strategy would be more effective if the salesperson decided to pause a few seconds before saying the punchline. This interruption could lead the client to use their positive thoughts generated by the merits of the product more. Of course, if the sales person noticed that the client counter-argues the proposition, generating negative thoughts about their products or services, then the most appropriate course of action, according to the results of this study, would be not to interrupt the joke. In fact, if the receiver generated negative thoughts about the proposition, it would not be persuasive to introduce a pleasant situation which could heighten the effect of those negative thoughts. 


\section{La interrupción de un chiste puede potenciar su efecto de validación del pensamiento y cambiar las actitudes hacia una empresa de reciclaje}

La investigación más reciente sobre emoción y cognición sugiere que las emociones pueden validar los pensamientos (Boden, Berenbaum, \& Gross, 2016; Clore \& Huntsinger, 2009; Huntsinger, Isbell, \& Clore, 2014). Aplicado al contexto del cambio de actitudes, una emoción positiva como la alegría puede aumentar o disminuir la persuasión dependiendo de la dirección de los pensamientos. Si los pensamientos de una persona son favorables hacia una propuesta persuasiva, entonces la alegría (al contrario que la tristeza) facilitará el uso de esos pensamientos positivos llevando a más persuasión. Por otro lado, si los pensamientos de la persona son desfavorables, la alegría (al contrario que la tristeza) facilitará el uso de esos pensamientos negativos, dando lugar, en este caso, a menos persuasión. Este efecto potenciador del pensamiento se debe a una sensación de seguridad (creer que uno tiene razón y está en lo cierto) y a otra de bienestar (sentirse a gusto con lo que viene a la mente). Si uno se siente bien y confía en la validez de pensamientos positivos, entonces la persuasión aumenta; pero si uno se siente bien y confía en la validez de pensamientos negativos, entonces la persuasión disminuye.

Este enfoque meta-cognitivo es consistente con las teorías de emoción denominadas del appraisal según las cuales las interpretaciones cognitivas de la situación influyen sobre las emociones y las emociones influyen sobre la interpretación cognitiva de las situaciones (Keltner \& Lerner, 2010; Smith \& Ellsworth, 1985). Por ejemplo, las emociones contienen dimensiones de valencia que nos ayudan a acercarnos a lo que nos gusta y a alejarnos de lo que nos desagrada. En nuestra aplicación meta-cognitiva de este enfoque (Petty \& Briñol, 2015), las emociones informan a las personas de los pensamientos que les atraen y les hacen sentir bien y de los pensamientos que rechazan o con los que no se sienten a gusto. Las emociones también contienen información sobre otros aspectos más allá de la valencia. Por ejemplo, algunas emociones como la alegría, además de hacernos sentir bien, están asociadas con sensaciones de seguridad y confianza (Moors, Ellsworth, Scherer, \& Frijda, 2013). Aplicado a la interpretación de nuestros propios pensamientos, la alegría nos hace sentir bien y seguros sobre lo que tenemos en mente, mientras que otras emociones como la tristeza nos harían sentir peor y más inseguros en relación con lo que pensamos.

En una primera ilustración de esta posibilidad, Briñol, Petty, y Barden (2007) llevaron a cabo una serie de experimentos donde los participantes primero recibieron un mensaje persuasivo compuesto por argumentos fuertes o un mensaje 
compuesto por argumentos débiles. Esta manipulación pretendía afectar a la dirección de los pensamientos generados, produciéndose más pensamientos favorables hacia el mensaje después de haber leído los argumentos fuertes, que después de haber leído los argumentos débiles. A continuación, se manipuló el estado de ánimo de los participantes pidiéndoles que escribieran experiencias personales en las cuales se sintieron alegres o tristes. Tras esta manipulación inicial, todos los participantes informaron de sus actitudes hacia la propuesta del mensaje. Tal y como se esperaba, se encontró que la alegría aumentó la confianza que tenían las personas en sus pensamientos y esta confianza llevó a actitudes más favorables hacia la propuesta persuasiva cuando los pensamientos eran positivos y a actitudes menos favorables cuando los pensamientos eran negativos.

Esta investigación demostró por primera vez en el ámbito del cambio de actitudes que las emociones positivas pueden operar a través de procesos de validación de los pensamientos en respuesta a mensajes persuasivos. Posteriormente, Paredes, Stavraki, Briñol, y Petty (2013) replicaron los efectos anteriormente descritos induciendo alegría a través de expresiones faciales de sonrisa y examinando su efecto sobre el uso de los pensamientos. En este trabajo, los participantes fueron expuestos primero a una historia diseñada para provocar pensamientos principalmente positivos (descripción de un buen día de un empleado en el trabajo) o negativos (narración sobre un mal día de un empleado en el trabajo). Después de escribir sus pensamientos, se pidió a los participantes que sostuvieran un bolígrafo con los dientes (condición de sonrisa) o con sus labios (condición control). Por último, todos los participantes informaron en qué medida les gustó la historia que leyeron sobre el empleado. De acuerdo con la hipótesis de auto-validación, se encontró que el efecto de la dirección de los pensamientos inicial sobre la evaluación de la historia fue mayor para los participantes en la condición de sonrisa que para los participantes en el grupo control. Sonreír aumentó el impacto positivo de los pensamientos positivos y también aumentó el impacto negativo de los pensamientos negativos. Estos resultados replicaron conceptualmente los obtenidos en investigaciones previas sobre cognición corporal (embodiment) pero solo cuando los participantes tuvieron pensamientos positivos. Es decir, la inducción de una expresión asociada con sonrisa produjo evaluaciones más favorables (Strack, Martin, \& Stepper, 1988) cuando se habían generado pensamientos positivos, aunque mostraron el patrón contrario de resultados (evaluaciones menos favorables para la condición de sonrisa) para los pensamientos negativos (véase Briñol, Petty, Santos, \& Mello, 2017, para una revisión).

En la presente investigación se estudia el efecto de validación del pensamiento de otra variable que con frecuencia se asocia a estados de ánimo positivos. En lugar de pedir a los participantes que recuerden acontecimientos pasados de alegría o inducirles sutilmente a adoptar expresiones faciales asociadas con la sonrisa, en este trabajo se expuso a los participantes a un chiste. En la medida en que los chistes pueden hacer que las personas se rían y se sientan bien, uno podría esperar que un chiste llevara a un mayor uso de los pensamientos como en el caso de las inducciones estudiadas anteriormente en este paradigma. En el presente 
estudio se compararon dos versiones de un mismo chiste: una versión con interrupción antes del desenlace y una versión en la que dicha interrupción no tuvo lugar antes del desenlace. La razón fundamental por la que se introdujo una interrupción fue para examinar en qué medida se podría potenciar el efecto del chiste en relación con el uso de los pensamientos. Evaluar si el efecto de los pensamientos aumenta o disminuye a la hora de formar una actitud permite estudiar en qué medida la interrupción constituye una variable de validación o invalidación del pensamiento. En principio, se pueden señalar una serie de razones que sugieren que el efecto de la interrupción en un chiste puede aumentar su efecto sobre el humor y, por tanto, aumentar el uso de los pensamientos dentro del contexto de la persuasión.

Primero, una interrupción puede potenciar el efecto de un chiste porque ralentiza la adaptación a experiencias positivas (Schmitt \& Zarantonello, 2013). Esta explicación es consistente con los resultados de distintos estudios que demuestran que los participantes que recibieron una interrupción en mitad de una experiencia positiva (e.g., recibir un masaje, entretenerse con el programa de televisión favorito) evaluaron su experiencia como más placentera que aquellos que recibieron la misma experiencia placentera de forma continuada (Nelson \& Meyvis, 2008; Nelson, Meyvis, \& Galak, 2009).

Segundo, la interrupción podría proporcionar un espacio para que las personas piensen sobre la experiencia que se va a producir a continuación y como consecuencia anticipen lo buena que va a seguir siendo. Es decir, las personas generarían expectativas sobre lo que les esperaría después de la pausa y, como la experiencia ya estaba resultando placentera, lo más probable es esperar que siguiera siendo agradable después. Esta interpretación resulta consistente también con el denominado fenómeno de mero pensamiento, según el cual cuanto más se piensa sobre algo más se polariza la respuesta evaluativa inicial (Clarkson, Tormala, \& Leone, 2011; Tesser \& Conlee, 1975). En línea con esta idea, Kupor y Tormala (2015) demostraron que una interrupción en un mensaje persuasivo puede aumentar el procesamiento de dicho mensaje por parte de los consumidores. Como resultado, los consumidores pueden ser más persuadidos por mensajes interrumpidos que por aquellos mismos mensajes si se ofrecieran sin interrupción.

Tercero, además de ralentizar la adaptación al placer y aumentar la generación de expectativas, existen otras razones por las cuales la interrupción podría aumentar el efecto del chiste. Por ejemplo, según Dijksterhuis, Bos, Nordgren, y Van Baaren (2006), cuando las decisiones son interrumpidas, las personas procesan la información del producto de acuerdo con sus deseos y, por tanto, eligen aquellas opciones que les resultan deseables en lugar de aquellas que les resultan factibles.

En cuarto lugar, Zeigarnik $(1927,1938)$ argumenta que interrumpir una tarea antes de su finalización produce un sentimiento de tensión no resuelta y una necesidad imperiosa por completarla. Esta tensión, a su vez, hace que se destinen recursos cognitivos a la tarea interrumpida, produciendo de esta manera un mejor recuerdo de tareas interrumpidas que de tareas no interrumpidas. Esta visión es 
consistente con el trabajo de Speier, Vessey, y Valacich (2003) quienes encontraron que debido al incremento del arousal provocado por la tensión que producen las tareas interrumpidas, el rendimiento posterior en distintas tareas aumentó, sobre todo en aquellas tareas que resultaron más sencillas (Bailey \& Konstan, 2006; Speier, Valacich, \& Vessey, 1999). Aplicado al campo de las actitudes, Pérez, Falomir, y Mugny (1995) encontraron que la interrupción de una tarea relacionada con la presentación de argumentos en un paradigma de influencia minoritaria aumentó el efecto persuasivo de dichos argumentos.

\section{Hipótesis y objetivo}

En resumen, la interrupción de un chiste puede potenciar su efecto porque aumenta la intensidad de la experiencia placentera y porque reduce la adaptación con la que normalmente las personas se acomodan en los estados de ánimo que resultan agradables. Tomadas conjuntamente estas interpretaciones, se podría esperar que la interrupción de un chiste tenga el potencial de aumentar el uso de cualquier pensamiento que pueda tener una persona en mente. Para poner a prueba esta posibilidad, en el presente estudio se empleará un paradigma en el que se evalúa el efecto de la interrupción de un chiste en relación con el uso de los pensamientos disponibles en ese momento a la hora de formar actitudes.

Conviene señalar que en la medida en que una persona experimente la interrupción como una pérdida de control y poder (Briñol, Petty, \& Stavraki, 2012), como una oportunidad para racionalizar la experiencia emocional (Wilson \& Gilbert, 2003) o como un espacio para que vengan a la mente pensamientos de valencia contraria a la inicial (Tormala, Falces, Briñol, \& Petty, 2007), el efecto de la interrupción podría reducir (en lugar de aumentar) el uso de los pensamientos. Finalmente, es posible que la interrupción del chiste no tenga ningún efecto en relación con el uso de pensamientos sobre propuestas persuasivas en un paradigma de auto-validación. Con el objetivo de esclarecer estas distintas posibilidades, se llevó a cabo el siguiente estudio.

\section{Método}

\section{Participantes y diseño}

Setenta y un estudiantes de la Universidad Autónoma de Madrid participaron de forma anónima y voluntaria en este estudio (ocho hombres, 61 mujeres y dos datos perdidos, con un rango de edad entre 21 y 27 años; $M_{\text {edad }}=21.76 ; S D=1.18$ ). Los participantes fueron aleatoriamente asignados a las condiciones de un diseño factorial inter-sujeto 2 (Calidad de los argumentos: Fuerte vs. Débil) $\times 2$ (Chiste: Interrupción antes del desenlace vs. Control).

\section{Procedimiento}

La investigación se presentó como un estudio sobre características organizacionales del entorno de trabajo de diferentes compañías. Se entregaron a los participantes 
cuestionarios que contenían las tareas que debían realizar y las instrucciones necesarias para llevarlas a cabo. Antes del inicio de la sesión, todos los participantes fueron informados de la confidencialidad y anonimato de la investigación, y se obtuvo su consentimiento informado. En primer lugar, los participantes leyeron una descripción completa de una compañía de reciclaje de nueva creación. En concreto, la descripción hacia la empresa era favorable en todos los casos y estaba compuesta, o bien por argumentos fuertes, o bien por argumentos débiles a favor de la idea de que la compañía era una empresa de reciclaje efectiva. Después de leer esta información, los participantes listaron sus pensamientos sobre esta compañía. Una vez escritos los pensamientos, a todos los participantes se les presentó un chiste en formato de tira cómica. Específicamente, a aquellos participantes en la condición de interrupción antes del desenlace se les pidió que pararan de leer la tira cómica antes de que el desenlace del chiste fuera presentado, mientras que a aquellos participantes en la condición de control se les pidió que pararan justo después del desenlace del chiste. Finalmente, todos los participantes evaluaron la empresa, completaron algunas medidas adicionales, se les agradeció su participación, se les explicó el objetivo y los detalles de la investigación, ofreciéndose además la posibilidad de ampliar información sobre la misma, y se solicitó su consentimiento para continuar con el análisis de los datos.

\section{Variables independientes}

Calidad de los argumentos. Los participantes recibieron un mensaje sobre una nueva compañía de reciclaje. Este mensaje estuvo compuesto por argumentos fuertes sobre la compañía para una condición o por argumentos débiles para la otra condición. Esta manipulación fue diseñada para influir en la favorabilidad de las respuestas cognitivas de los participantes hacia la compañía y su eficacia ha quedado contrastada en investigaciones previas (Horcajo, Petty, \& Briñol, 2010). Es decir, los argumentos fuertes generaron mayoritariamente pensamientos favorables hacia la compañía y los argumentos débiles generaron mayoritariamente pensamientos desfavorables (para ejemplos en castellano sobre la manipulación de la calidad de los argumentos, véase

Gandarillas, Requero, Rojo, \& Briñol, 2014). Algunos de los argumentos fuertes a favor de la compañía fueron que los trabajadores reportaban una mayor satisfacción debido a la flexibilidad de sus horarios de trabajo y la inversión en formación por parte de la compañía, que había una libertad y autonomía total para innovar, que las decisiones de promoción se tomaban basadas en los méritos de los trabajadores y no en amiguismos, que la compañía invertía en energías renovables y utilizaba políticas protectoras del medio ambiente, y se guiaba por políticas de igualdad (e.g., con un gran número de mujeres en los puestos directivos). Por el contrario, algunos de los argumentos débiles a favor de la compañía fueron que usaban papel no reciclado para tener una imagen pública buena, que el logo de la compañía era muy atractivo, que las oficinas proyectaban una imagen respetuosa con el medio ambiente al tener muchas plantas alrededor de la compañía, que se preocupaban por los empleados teniendo máquinas expendedoras en las oficinas, y que la compañía se preocupaba por la flexibilidad ya que muchos de los empleados trabajaban allí sólo temporalmente. Los argumentos fueron diseñados y pre-testados para inducir mayoritariamente 
pensamientos positivos (en respuesta a los argumentos fuertes del mensaje) o pensamientos negativos (en respuesta a los argumentos débiles del mensaje).

Chiste. Después de leer el mensaje y listar sus pensamientos, los participantes fueron expuestos a una tira cómica compuesta por seis viñetas. En ambas condiciones se usó el mismo chiste. En la condición de interrupción antes del desenlace, se mostró a los participantes las seis viñetas en una página pero con las dos últimas viñetas en blanco, dejando así que vieran solamente cuatro viñetas del chiste. Se pidió a los participantes que pararan dos minutos antes de leer las últimas dos viñetas, presentadas en la página siguiente. Es decir, los participantes pararon justo antes de que el desenlace del chiste fuera presentado. Por otro lado, en la condición control, se mostró a los participantes las seis viñetas en una página y se les pidió que pararan al final de la tira cómica y que esperasen dos minutos antes de continuar con el resto del experimento. Es decir, los participantes en esta condición vieron la tira cómica completa, incluyendo el desenlace del chiste. Después de ver la tira cómica completa, los participantes recibieron instrucciones de parar dos minutos antes de seguir con el resto del estudio para que ambas condiciones quedaran equiparadas en el tiempo total de presentación.

\section{Variables dependientes}

Favorabilidad de los pensamientos. Se instruyó a los participantes para que listaran los pensamientos que habían tenido al leer el mensaje. Se les proveyó con 10 casillas para listar hasta 10 pensamientos. Se les dijo que debían escribir un pensamiento por casilla y que no se preocuparan por aspectos gramaticales (para detalles adicionales sobre la tarea de listado de pensamientos, veáse Briñol, Petty, \& Tormala, 2004; para otro ejemplo en castellano, véase Martín-Fernández, Santos, Requero, \& Cedeño, 2014). Al final del experimento, se presentó a los participantes de nuevo los pensamientos que habían escrito, y se les pidió que los clasificaran como positivos, negativos o neutros con respecto a la compañía. Se creó un índice de favorabilidad de los pensamientos para cada participante substrayendo el número de pensamientos negativos del número de pensamientos positivos que había listado cada uno. Finalmente, esta puntuación diferencial fue dividida por el número total de pensamientos listados.

Actitudes. Se pidió a los participantes que evaluaran a la compañía mediante una serie de escalas de diferencial semántico de nueve puntos (1-9) (i.e., 'nada interesante-muy interesante', 'nada completa-muy completa', 'nada recomendable-muy recomendable', 'nada deseable-muy deseable para trabajar', 'no me gusta-me gusta'). Debido a la alta correlación interna presentada por estos cinco ítems $(\alpha=.96)$, se compuso un índice general de actitudes hacia la empresa para cada participante con el promedio en sus puntuaciones. Los valores más altos en esta escala indicaron una mayor favorabilidad hacia la empresa.

Medidas complementarias. Después de la medida de actitudes, todos los participantes indicaron en una escala de 1 a 9 la atención prestada al experimento, el nivel de precisión con el que habían completado el cuestionario, el grado en el que 
habían tratado de ocultar sus respuestas, el grado en el que creían haber descubierto el objetivo del experimento, el grado en el que el desenlace del chiste les había sorprendido y el grado en el que habían entendido el chiste.

\section{Resultados}

\section{Favorabilidad de los pensamientos}

El ANOVA 2 (Calidad de los argumentos: Fuertes vs. Débiles) $\times 2$ (Chiste: Interrupción antes del desenlace vs. Control) realizado sobre los pensamientos de los participantes reveló un efecto principal de la variable calidad de los argumentos, $F(1,66)=195.76, p<.001, \eta^{2}=.75$. Tal y como se muestra en la Figura 1, los participantes generaron pensamientos más favorables en la condición de argumentos fuertes $(M=0.69, S D=0.34)$ que en la condición de argumentos débiles $(M=-0.71, S D=0.47)$. No se encontró ningún otro efecto principal o de interacción, $p \mathrm{~s}>.094$.

\section{Actitudes}

El ANOVA $2 \times 2$ reveló un efecto principal de la variable calidad de los argumentos que indicó que los participantes que recibieron el mensaje fuerte reportaron actitudes más favorables hacia la empresa $(M=7.63, S D=0.95)$ que aquellos que recibieron el mensaje débil $(M=3.32, S D=1.30), F(1$, $67)=258.84, p<.001, \eta^{2}=.79$. Además, tal y como se esperaba, la interacción entre la calidad de los argumentos y el chiste resultó estadísticamente significativa, $F(1,67)=7.18, p=.009, \eta^{2}=.10$. Para los participantes que leyeron el chiste y pararon antes del desenlace, aquellos que recibieron el mensaje fuerte evaluaron la compañía como más favorable $(M=7.95, S D=0.99)$ que aquellos que recibieron el mensaje débil $(M=3.01$, $S D=1.27), F(1,67)=195.71, p<.001, \eta^{2}=.75$. Por otro lado, entre los

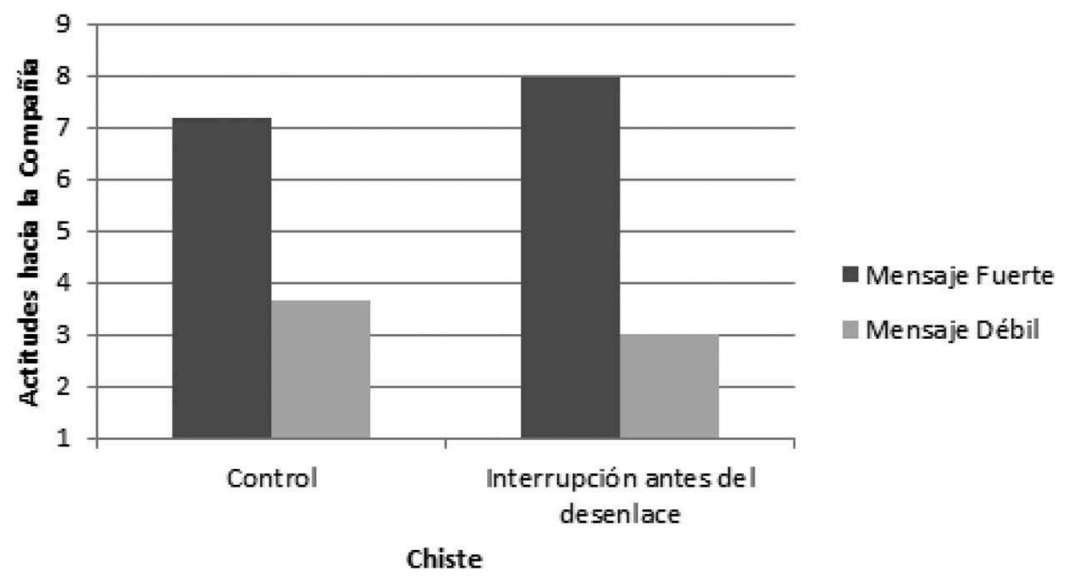

Figura 1. Actitudes hacia la compañía en función de la calidad de los argumentos y el chiste. 
participantes que leyeron el chiste seguido y pararon al final (condición control), aquellos que recibieron el mensaje fuerte también reportaron actitudes más favorable hacia la compañía $(M=7.20, S D=0.73)$ que aquellos que recibieron el mensaje débil $(M=3.67, S D=1.28), F(1,67)=81.72, p<.001, \eta^{2}=.55$, aunque esta diferencia fue más pequeña comparada con los participantes que pararon antes del desenlace del chiste. Es decir, el efecto de la calidad de los argumentos sobre las actitudes fue mayor para aquellos participantes que pararon antes de leer el desenlace que para aquellos participantes en la condición control.

Descompuesta de otra manera, esta interacción demuestra que, en la condición de mensaje fuerte, los participantes que pararon antes del desenlace reportaron actitudes más favorable hacia la compañía $(M=7.95, S D=0.99)$ que los participantes en la condición control $(M=7.20, S D=0.73), F(1,67)=3.97$, $p=.050, \eta^{2}=.06$. Por el contrario, entre los participantes en la condición de mensaje débil, aquellos que pararon antes del desenlace tendieron a reportar actitudes menos favorables $(M=3.01, S D=1.27)$ que aquellos en la condición control $(M=3.67, S D=1.28), F(1,67)=3.22, p=.077, \eta^{2}=.05$.

\section{Relación pensamientos-actitudes}

Una de las predicciones de la auto-validación es que el vínculo entre los pensamientos y las actitudes debe ser mayor para la condición de validación que para el grupo control. Para comprobar esta hipótesis sobre la relación entre pensamientos y actitudes, se llevó a cabo un análisis de regresión incluyendo como variables predictoras la calidad de los argumentos, el chiste y el índice de favorabilidad de los pensamientos, y como variable dependiente las actitudes. Tal y como se muestra en la Figura 2, la interacción entre la favorabilidad de los pensamientos y el chiste resultó estadísticamente significativa, $B=-1.043, t(68)=-2.855$, $p=.006$. Este patrón interactivo indicó que, aunque la favorabilidad de los pensamientos predijo las actitudes en toda la muestra, esta relación entre

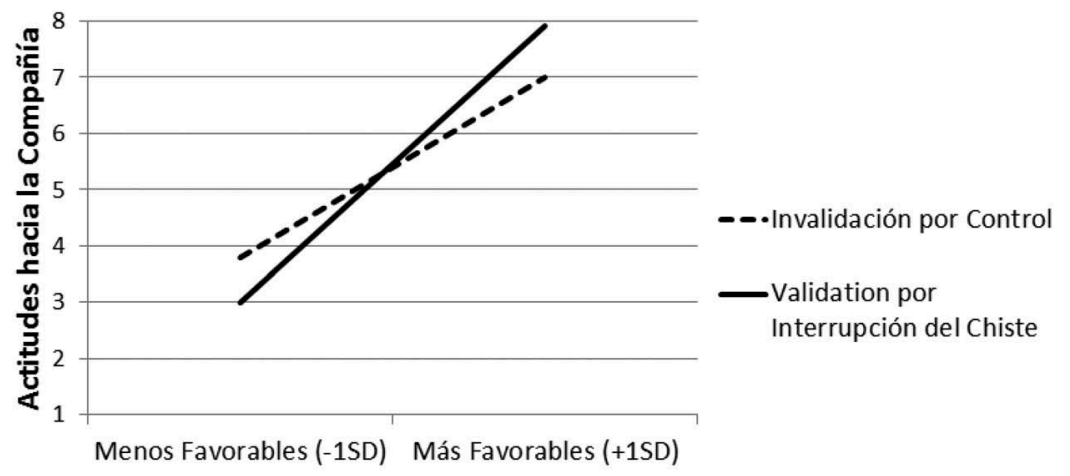

Favorabilidad de los Pensamientos

Figura 2. Relación entre la favorabilidad de los pensamientos y las actitudes en función de la validación mediante la interrupción del chiste (vs. control). 
constructos mentales fue mayor para los participantes en la condición de interrupción del chiste $(B=3.020, t(68)=13.117, p<.001)$ que para aquellos en la condición control $(B=1.977, t(68)=6.971, p<.001)$.

\section{Medidas complementarias}

No se encontró ningún efecto principal ni de interacción en ninguno de los ítems complementarios (i.e., precisión, atención, cantidad de elaboración, sospecha, sorpresa y entendimiento), $p \mathrm{~s}>.16$.

\section{Discusión y conclusiones}

La investigación sobre auto-validación demuestra que emociones como la alegría validan los pensamientos de las personas. La validación del pensamiento tiene lugar tanto si esos pensamientos son positivos como si son negativos. Como se ha señalado, este efecto potenciador del pensamiento se debe a una sensación de seguridad (creer que uno tiene razón y está en lo cierto) y a otra de bienestar (sentirse a gusto con lo que viene a la mente). A diferencia de las inducciones de alegría estudiadas hasta ahora (centradas en el receptor), el presente trabajo examinó una inducción a partir de un chiste. Además, se estudió el efecto de una interrupción del chiste con objeto de evaluar su posible efecto de validación del pensamiento.

Según los resultados encontrados, el efecto de los pensamientos sobre las actitudes fue mayor para aquellos participantes que tuvieron que parar antes del desenlace del chiste en comparación con aquellos que leyeron el chiste seguido (condición control). Dicho de otra manera, los participantes que vieron el chiste interrumpido usaron más sus pensamientos para formar sus actitudes hacia la compañía sobre la que habían leído inicialmente que aquellos que vieron el chiste seguido.

Como se describió en la introducción, la interrupción de una experiencia hedónica puede tener efectos positivos al aumentar su intensidad (Nelson \& Meyvis, 2008; Nelson et al., 2009). Este efecto positivo podría hacer que las personas validaran sus pensamientos y los usaran para hacer evaluaciones posteriores. Es decir, el efecto positivo de la interrupción del chiste podría hacer que se confiara y que gustara más lo que se piensa, formándose actitudes coherentes con respecto a los pensamientos que se tengan en mente en ese momento. Como resultado de esta validación de los pensamientos, cuando esos pensamientos hacia la compañía fueron positivos y el chiste se interrumpió, se formaron actitudes más favorables hacia la compañía que cuando no se interrumpió. Por el contrario, cuando las personas generaron pensamientos negativos hacia la empresa y el chiste fue interrumpido, éstas formaron actitudes menos favorables que cuando no fue interrumpido.

Aunque los resultados del estudio sugieren que una interrupción puede validar lo que piensan las personas, también hay otras posibles explicaciones que pueden dar cuenta de los resultados obtenidos. Primero, se podría argumentar que la parada antes 
del desenlace del chiste afectó a la cantidad de pensamiento, incrementando la elaboración del mensaje inicial en lugar de influir sobre el uso de los mismos. De hecho, los participantes en la condición de parada antes de la resolución tuvieron tiempo para prestar atención a los pensamientos generados hacia la compañía. Aunque esta interpretación es plausible consideramos que no resulta probable ya que el chiste siguió (en lugar de preceder) la lectura del mensaje. Es decir, los participantes primero fueron expuestos al mensaje, luego listaron sus pensamientos y a continuación vieron el chiste. Este orden de acontecimientos hace improbable que los pensamientos generados en respuesta a la compañía se vieran influidos por algo que ocurrió con posterioridad. De hecho, los participantes listaron la misma cantidad de pensamientos en todas las condiciones, lo que sugiere que la condición de parada antes del desenlace no aumentó la cantidad del pensamiento comparado con la condición de parada después del desenlace del chiste. Además, cuando los participantes fueron explícitamente preguntados por la atención prestada en la lectura de los mensajes, no se obtuvo ninguna diferencia en función de las condiciones del chiste. Consecuentemente, ni los indicadores objetivos (número de pensamientos listados) de cantidad de pensamiento ni los subjetivos (atención) son consistentes con esta interpretación alternativa.

Otra posible explicación sería que la parada antes del desenlace pudo afectar a la facilidad con la que se leyó el chiste o a la comprensión del mismo, dado que la parada proporcionó a los participantes no sólo tiempo para pensar retrospectivamente sobre la empresa sino también tiempo para pensar sobre el posible desenlace futuro del chiste. De este modo, los participantes pudieron generar hipótesis sobre cómo terminaría el chiste. Posteriormente, si alguna de estas expectativas fue confirmada cuando se presentó el desenlace real, se pudo producir un encaje (matching) entre la expectativa y el resultado, y dicha convergencia aumentaría la facilidad percibida de la tarea (Schwarz et al., 1991; Topolinski, 2014; para una revisión, veáse Briñol et al., 2013). A pesar del interés que pueda tener esta interpretación, que no es del todo incompatible con nuestra propuesta (ya que los fenómenos de encaje pueden aumentar la validez del pensamiento; Clark, Wegener, Briñol, \& Petty, 2009, 2013), no se encontraron diferencias entre las condiciones de interrupción en relación con la dificultad a la hora de entender el chiste.

Una tercera posibilidad sería que los participantes tuvieron una mayor necesidad de cierre cognitivo cuando pararon antes del desenlace del chiste que cuando pararon después (Kruglanski, 2004). Según esta explicación, la interrupción pudo motivar una necesidad de resolver la situación con cualquier información disponible en ese momento, que en este caso fueron los pensamientos generados anteriormente sobre la empresa.

Parcialmente relacionado con esta posibilidad, la interrupción pudo suponer una ruptura de los esquemas y una violación de las expectativas que pudo resultar desagradable para los participantes. Se sabe que la confusión puede resultar amenazante en algunos casos dando lugar a una utilización de los pensamientos disponibles en ese momento como una forma de compensar el malestar y restablecer el orden perdido (Briñol et al., 2015). Una quinta explicación alternativa es que la interrupción podría aumentar la intensidad del chiste y esto llevara a una evaluación más global de los pensamientos, o podría concentrar la atención de 
forma más precisa en los pensamientos relevantes (sin distracciones), o incluso a una mayor generalización a otros pensamientos (Fredrickson \& Branigan, 2005; Horcajo, Briñol, \& Petty, 2010).

Futuros trabajos deberán contar con un mayor número de medidas que permitan esclarecer algunas de estas posibilidades, tales como la escala de necesidad de cierre cognitivo (para la versión en castellano de esta escala, véase Horcajo, Díaz, Gandarillas, \& Briñol, 2011) así como la dirección e intensidad de las emociones producidas en respuesta al chiste. En futuras investigaciones también conviene que los resultados sean replicados con distintos objetos de actitud y otras maneras de manipular la parada tanto dentro del contexto del humor como de otras experiencias placenteras (Briñol, Stavraki, Horcajo, \& Gandarillas, 2016). Por último, cabe mencionar como limitación del presente estudio que el actual diseño no permite determinar de forma definitiva en qué medida la interrupción del chiste incrementó el uso de los pensamientos o el grupo control redujo dicho uso, o si se produjo una combinación de ambos efectos. Incluir un grupo sin chiste permitiría mayor alumbramiento sobre esta cuestión. En cualquier caso, el objetivo principal del presente trabajo fue examinar en qué condiciones un chiste podía llevar a un mayor o menor uso de pensamientos.

Para terminar, conviene señalar que una interrupción no necesariamente aumenta el efecto de un chiste en todas las situaciones y para todas las personas. Existen variables que pueden influir sobre en qué medida, cuándo y por qué la interrupción potencia o reduce el efecto de una experiencia. Por ejemplo, la interrupción puede reducir el efecto de una experiencia placentera (el efecto de un chiste) en la medida en que permita que vengan a la mente pensamientos de la valencia contraria a la inicial (Forgas \& Ciarrochi, 2002; Koole \& Jostmann, 2004; Tormala et al., 2007), en la medida en que dé una oportunidad para racionalizar la experiencia emocional (Wilson \& Gilbert, 2003), cuando esté asociada con una pérdida de control (Briñol et al., 2007, 2013), y cuando se perciba como una tarea que no se ha podido resolver (Stavraki, Santos, Cancela, Requero, \& Briñol, 2017). En realidad, cualquier asociación negativa con la interrupción podría reducir (en lugar de aumentar) el efecto sobre los pensamientos. Además, en la medida en que una interrupción sea inesperada, viole las expectativas iniciales o suponga una sorpresa también podría reducir el uso de los pensamientos, al menos en la medida en que las personas se centren en estos aspectos potenciales de duda e incertidumbre.

En cuanto a las posibles aplicaciones prácticas, considere el escenario donde un vendedor está tratando de convencerle de que compre sus productos o los servicios de su compañía. Después de demostrarle los méritos de su propuesta, el vendedor utiliza un chiste para cerrar la venta. En función de los resultados del presente trabajo, se podría especular que esta estrategia resultaría más efectiva si el vendedor decide parar unos segundos justo antes de proporcionar el desenlace del chiste. Esta parada podría llevar al cliente a usar más sus pensamientos positivos generados por los méritos de los productos. Por supuesto, si el vendedor observase que el cliente contra-argumenta la propuesta generando pensamientos negativos sobre sus productos o servicios, entonces lo más apropiado según los 
resultados del trabajo sería no interrumpir el chiste. De hecho, en el caso de que el receptor genere pensamientos negativos acerca de la propuesta no resultaría persuasivo introducir a continuación una situación placentera que pudiera potenciar el efecto de dichos pensamientos.

\section{Acknowledgements / Agradecimentos}

This research was made possible thanks to the funding awarded by the Ministry of Economy and Competitiveness of Spain (Ref. PSI2017-83303-C2-1-P). / El presente trabajo de investigación ha sido posible gracias a la financiación concedida por el Ministerio de Economía y Competitividad de España (Ref. PSI2017-83303-C2-1-P).

\section{Disclosure statement}

No potential conflict of interest was reported by the authors. / Los autores no han referido ningún potencial conflicto de interés en relación con este artículo.

\section{ORCID}

David Santos (D) http://orcid.org/0000-0001-9786-5219

\section{References / Referencias}

Bailey, B. P., \& Konstan, J. A. (2006). On the need for attention-aware systems: Measuring effects of interruption on task performance, error rate, and affective state. Computers in Human Behavior, 22, 685-708.

Boden, M. T., Berenbaum, H., \& Gross, J. J. (2016). Why do people believe what they do? A functionalist perspective. Review of General Psychology, 20, 399-411.

Briñol, P., Petty, R. E., \& Barden, J. (2007). Happiness versus sadness as determinants of thought confidence in persuasion: A self-validation analysis. Journal of Personality and Social Psychology, 93, 711-727.

Briñol, P., Petty, R. E., \& DeMarree, K. (2015). Being threatened and being a threat can increase reliance on thoughts: A self-validation approach. In P. J. Carroll, R. M. Arkin, \& A. Wichman (Eds.), Handbook on personal security (pp. 37-54). New York, NY: Psychology Press.

Briñol, P., Petty, R. E., Santos, D., \& Mello, J. (2017). Meaning moderates the persuasive effect of physical actions: Buying, selling, touching, carrying, and cleaning thoughts as if they were commercial products. Journal of the Association for Consumer Research, 2, 460-471.

Briñol, P., Petty, R. E., \& Stavraki, M. (2012). Power increases the reliance on firstimpression thoughts. Revista de Psicología Social, 27, 293-303.

Briñol, P., Petty, R. E., \& Tormala, Z. L. (2004). Self-validation of cognitive responses to advertisements. Journal of Consumer Research, 30, 559-573.

Briñol, P., Petty, R. E., Valle, C., Rucker, D. D., \& Becerra, A. (2007). The effects of message recipients' power before and after persuasion: A self-validation analysis. Journal of Personality and Social Psychology, 93, 1040-1053.

Briñol, P., Stavraki, M., Horcajo, J., \& Gandarillas, B. (2016). Emoción y persuasión. In I. Schweiger \& J. R. Torregrosa (Eds.), Perspectivas en el estudio de las emociones. (pp. 85-122) Madrid: Editorial Grupo 5.

Briñol, P., Tormala, Z. L., \& Petty, R. E. (2013). Ease and persuasion: Multiple processes, meanings, and effects. In C. Unkelbach \& R. Greifeneder (Eds.), The experience of 
thinking: How the fluency of mental processes influences cognition and behaviour (pp. 101-118). London: Psychology Press.

Clark, J. K., Wegener, D. T., Briñol, P., \& Petty, R. E. (2009). Discovering that the shoe fits: The self-validating role of stereotypes. Psychological Science, 20, 846-852.

Clark, J. K., Wegener, D. T., Sawicki, V., Petty, R. E., \& Briñol, P. (2013). Evaluating the message or the messenger? Implications for self-validation in persuasion. Personality and Social Psychology Bulletin, 39, 1571-1584.

Clarkson, J. J., Tormala, Z. L., \& Leone, C. (2011). A self-validation perspective on the mere thought effect. Journal of Experimental Social Psychology, 47, 449-454.

Clore, G. L., \& Huntsinger, J. R. (2009). How the object of affect guides its impact. Emotion Review, 1, 39-54.

Dijksterhuis, A., Bos, M. W., Nordgren, L. F., \& Van Baaren, R. B. (2006). On making the right choice: The deliberation-without-attention effect. Science, 311, 1005-1007.

Forgas, J. P., \& Ciarrochi, J. V. (2002). On managing moods: Evidence for the role of homeostatic cognitive strategies in affect regulation. Personality and Social Psychology Bulletin, 28, 336-345.

Fredrickson, B. L., \& Branigan, C. (2005). Positive emotions broaden the scope of attention and thought-Action repertoires. Cognition \& Emotion, 19, 313-332.

Gandarillas, B., Requero, B., Rojo, B., \& Briñol, P. (2014). El efecto de la responsabilidad organizacional sobre las actitudes hacia la contratación de personas con discapacidad. Universitas Psychologica, 14, 15-24.

Horcajo, J., Briñol, P., \& Petty, R. E. (2010). Consumer persuasion: Indirect change and implicit balance. Psychology and Marketing, 27, 938-963.

Horcajo, J., Díaz, D., Gandarillas, B., \& Briñol, P. (2011). Adaptación al castellano del Test de Necesidad de Cierre Cognitivo. Psicothema, 23, 864-870.

Horcajo, J., Petty, R. E., \& Briñol, P. (2010). The effects of majority versus minority source status on persuasion: A self-validation analysis. Journal of Personality and Social Psychology, 99, 498-512.

Huntsinger, J. R., Isbell, L., \& Clore, G. L. (2014). The affective control of thought: Malleable, not fixed. Psychological Review, 121, 600-618.

Keltner, D., \& Lerner, J. S. (2010). Emotion. In S. Fiske, D. T. Gilbert, \& G. Lindzey (Eds.), Handbook of social psychology (Vol. 1, 5th ed., pp. 317-352). New York, NY: Random House.

Koole, S. L., \& Jostmann, N. B. (2004). Getting a grip on your feelings: Effects of action orientation and external demands on intuitive affect regulation. Journal of Personality and Social Psychology, 87, 974-990.

Kruglanski, A. W. (2004). The psychology of closed-mindedness. New York, NY: Psychology Press.

Kupor, D. M., \& Tormala, Z. L. (2015). Persuasion, interrupted: The effect of momentary interruptions on message processing and persuasion. Journal of Consumer Research, $42,300-315$.

Martín-Fernández, M., Santos, D., Requero, B., \& Cedeño, M. (2014). Cambio de actitudes hacia la diversidad afectivo-sexual: La reducción de la percepción del intento persuasivo. Revista Colombiana de Psicología, 23, 107-118.

Moors, A., Ellsworth, P. C., Scherer, K. R., \& Frijda, N. H. (2013). Appraisal theories of emotion: State of the art and future development. Emotion Review, 5, 119-124.

Nelson, L. D., \& Meyvis, T. (2008). Interrupted consumption: Disrupting adaptation to hedonic experiences. Journal of Marketing Research, 45, 654-664.

Nelson, L. D., Meyvis, T., \& Galak, J. (2009). Enhancing the television-viewing experience through commercial interruptions. Journal of Consumer Research, 36, 160-172.

Paredes, B., Stavraki, M., Briñol, P., \& Petty, R. E. (2013). Smile after thinking: Smiling increases reliance in thoughts. Social Psychology, 44, 349-353. 
Pérez, J. A., Falomir, J. M., \& Mugny, G. (1995). Internalization of conflict and attitude change. European Journal of Social Psychology, 25, 117-124.

Petty, R. E., \& Briñol, P. (2015). Emotion and persuasion: Cognitive and meta-cognitive processes impact attitudes. Cognition and Emotion, 29, 1-26.

Schmitt, B., \& Zarantonello, L. (2013). Consumer experience and experiential marketing: A critical review. Review of Marketing Research, 10, 25-61.

Schwarz, N., Bless, H., Strack, F., Klumpp, G., Rittenauer-Schatka, H., \& Simons, A. (1991). Ease of retrieval as information: Another look at the availability heuristic. Journal of Personality and Social Psychology, 61, 195-202.

Smith, C. A., \& Ellsworth, P. C. (1985). Patterns of cognitive appraisal in emotion. Journal of Personality and Social Psychology, 48, 813-838.

Speier, C., Valacich, J. S., \& Vessey, I. (1999). The influence of task interruption on individual decision making: An information overload perspective. Decision Sciences, 30, 337-360.

Speier, C., Vessey, I., \& Valacich, J. S. (2003). The effects of interruptions, task complexity, and information presentation on computer-supported decision-making performance. Decision Sciences, 34, 771-797.

Stavraki, M., Santos, D., Cancela, A., Requero, B., \& Briñol, P. (2017). The evaluation of green companies changes after remembering tip of the tongue experiences. Psicothema, 29, 502-507.

Strack, F., Martin, L. L., \& Stepper, S. (1988). Inhibiting and facilitating conditions of the human smile: A nonobtrusive test of the facial feedback hypothesis. Journal of Personality and Social Psychology, 54, 768-777.

Tesser, A., \& Conlee, M. C. (1975). Some effects of time and thought on attitude polarization. Journal of Personality and Social Psychology, 31, 262-270.

Topolinski, S. (2014). A processing fluency-account of funniness: Running gags and spoiling punchlines. Cognition and Emotion, 28, 811-820.

Tormala, Z. L., Falces, C., Briñol, P., \& Petty, R. E. (2007). Ease of retrieval effects in social judgment: The role of unrequested cognitions. Journal of Personality and Social Psychology, 93, 143-157.

Wilson, T. D., \& Gilbert, D. T. (2003). Affective forecasting. In M. P. Zanna (Ed.), Advances in experimental social psychology (Vol. 35, pp. 345-411). San Diego, CA: Academic Press.

Zeigarnik, B. (1927). Über das Behalten von erledigten und unerledigten Handlungen. Psychologische Forschung, 9, 1-85.

Zeigarnik, B. (1938). On finished and unfinished tasks. In W. D. Ellis (Ed.), A source book of Gestalt psychology (pp. 300-314). London: Kegan Paul, Trench, Trubner \& Company. 